\title{
RHEUMATIC FEVER AND RHEUMATIC HEART DISEASE IN CHILDREN BELOW THE AGE OF 5 YEARS IN THE TROPICS
}

\author{
BY \\ ZAHIRA H. ABDIN AND A. EISSA \\ From the Rheumatic and Heart Unit, Children's Hospital, Cairo University, Egypt
}

Rheumatic fever and particularly rheumatic heart disease have always been regarded as rare conditions below the age of 5 years and as very rare below 3 years (Holt and McIntosh, 1953). Reported cases are few and no account of the clinical pattern of the disease in the small child has been found in the literature.

In the Rheumatic and Heart Clinic, in Cairo University Hospital, we have had the opportunity of examining large numbers of children referred with rheumatic fever and rheumatic heart disease in the last 4 years. It was thus possible to collect a fairly large group of younger children with the disease and we were able to examine the incidence as well as the special features of rheumatic fever and rheumatic heart disease in this age group.

\section{Material and Method}

1,000 proven cases of juvenile rheumatic fever and rheumatic heart disease were selected from the patients attending the Rheumatic and Heart Clinic. The few patients without cardiac involvement had either chorea or rheumatoid arthritis; the latter were carefully differentiated from other types of arthritis by the clinical pattern, anti-streptolysin titre, differential sheep cell agglutination test, family history, and follow-up.

In patients below the age of 5 years the type of heart affection, general clinical pattern, general incidence, sex distribution, familial or social background, and blood groups were noted.

\section{Results}

Among the thousand children were 68 patients below 5 years, including 26 below 4 years. The general incidence for these younger children was thus 6.8 and 2.6 per cent. respectively.

The youngest patient was a girl aged 9 months with rheumatic arthritis who eventually developed carditis. Two others were aged 11 months and 18 months at onset respectively. The youngest child with chorea was a boy aged 2 years and 8 months. The history and main clinical finding in these four cases is given in the footnote below.*

The sex distribution was 42 females to 26 males, i.e. $2 \cdot 4: 1$ compared to a general incidence of $1 \cdot 7: 1$ (Table I).

TABLE I

SEX RATIO AND FAMILIAL TENDENCY

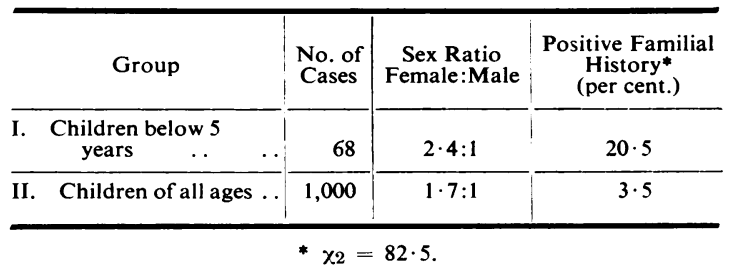

Fourteen patients had a positive family history, often in a brother or sister, less frequently in a mother or father. The familial incidence was thus $20 \cdot 5$ per cent. against a familial tendency of $3 \cdot 5$ per cent. in the whole series. This high familial tendency in the younger children is rather striking (Table I).

* Summary of Four Youngest Patients

Case 1, a girl aged 3 years, who was first seen at the age of 9 months with fever $\left(38 \cdot 7^{\circ} \mathrm{C}\right.$.), painful swelling of the knees and ankles, and a grade 3 pansystolic murmur over the apex, eventually developed antistreptolysin titre 1:400 and differential agglutination titre 1:4 antistreptolysin titre $1: 400$ and differential agglutination titre $1: 4$
She was treated with rest and aspirin for 2 months in hospital, discharged to the follow-up clinic, and kept under prophylactic penicillin. She eventually lost the murmur 9 months after discharge. She had a relapse 6 months later, when a short mitral diastolic murmur was heard, but this was transient and was not heard 1 month later.

Case 2, a girl aged 5 years, was first seen when aged 2 years with Case 2, a girl aged 5 years, was first seen when aged 2 years with history of flitting arthritis 6 months before. There was moderate heart history of flitting arthritis 6 months before. There was moderate heart
enlargement, mainly left ventricular. A pansystolic murmur grade
$3: 4$ was well propagated out but also heard inwards and in the back, with a pericardial rub. She has now been under prophylactic therapy for 3 years, with no relapses and hardly any alteration in the murmur or in the size of the heart.

Case 3, a boy aged 11 months, had flitting arthritis antistreptolysin titre $1: 400$ D.A.T.1:4. His brother now 5 years old had rheumatic heart disease with mitral incompetence and enlarged heart and a history of disease with mitral incompetence and enlarged heart and a history of flitting arthritis and fever at age 2 . The younger boy responded well
to salicylates and rest, with no subsequent heart affection, and no to salicylates and rest, with no subse
prophylactic penicillin for 2 years.

Case 4, a boy aged 2 years 8 months, presented with moderate to severe choreic movements, enlarged heart, and an apical pansystolic murmur grade 3 slightly propagated. 
The incidence of simple arthritis, chorea, and carditis was $13 \cdot 2,7 \cdot 3$, and $79 \cdot 4$ per cent. respectively compared to the general incidence of $11 \cdot 2$, $12 \cdot 3$, and $79 \cdot 5$ per cent. (Table II).

TABLE II

INCIDENCE OF MAIN MANIFESTATIONS OF RHEUMATIC DISEASE

\begin{tabular}{c|c|c|c}
\hline \multirow{2}{*}{ Group } & \multicolumn{3}{|c}{ Manifestations (per cent.) } \\
\hline Irthritis & Chorea $^{*}$ & Carditis \\
\hline I & $13 \cdot 2$ & $7 \cdot 3$ & $79 \cdot 4$ \\
\hline II & $11 \cdot 2$ & $12 \cdot 3 \dagger$ & $79 \cdot 5$ \\
\hline
\end{tabular}

* This includes simple chorea and chorea + carditis. $+\chi^{2}=-3 \cdot 4$

The type of valvular lesion is shown in Table III. There is a higher incidence of mitral incompetence and a lower incidence of mitral stenosis in the younger children.

TABLE III

DISTRIBUTION OF VALVULAR LESIONS AMONG CASES WITH HEART DISEASE (PER CENT.)

\begin{tabular}{c|c|c|c|c}
\hline Group & $\begin{array}{c}\text { Mitral } \\
\text { Incompe- } \\
\text { tence }\end{array}$ & $\begin{array}{c}\text { Mitral } \\
\text { Stenosis }\end{array}$ & $\begin{array}{c}\text { Aortic } \\
\text { Regurgita- } \\
\text { tion }\end{array}$ & $\begin{array}{c}\text { Aortic } \\
\text { Stenosis }\end{array}$ \\
\hline I & $23 \cdot 6$ & $5 \cdot 3$ & $3 \cdot 6$ & $1 \cdot 8$ \\
\hline$\chi^{2}$ & $+9 \cdot 68$ & $-3 \cdot 4$ & -5 & $2 \cdot 5$ \\
\hline
\end{tabular}

24 patients had some degree of cardiac enlargement ( $\stackrel{\mathrm{T}}{\mathrm{T}}$ over 55 per cent.) and in nine of these the enlargement was gross or was associated with evidence of congestive heart failure (Figs 1 and 2). Six of these nine patients were 3 years old or below. The incidence of severe heart disease is 35.2 per cent. compared to 38 per cent. in the general series.

The incidence of sore throat was noted, but swabs and cultures were not taken routinely for this series; 51 cases ( 75 per cent. of the whole series) had an attack of sore throat shortly preceding or concomitant with the rheumatic manifestations, or had had recurrent attacks of sore throat in their past history.

Finally, the patients' blood groups seemed to be of interest: 45.7 per cent. were group $A, 20$ per cent. group $\mathrm{B}, 5 \cdot 7$ per cent. group $\mathrm{AB}$, and $28 \cdot 5$ per cent. group $O$. Thus, though the prevalence of group $A$ was maintained, the scarcity of group $O$ was less marked than usual.

\section{Comment}

In a previous study rheumatic fever and rheumatic heart disease have been shown to be common in our community (Abdin, 1960; Ibrahim, 1960); this is contrary to the general opinion that rheumatic fever is a rare disease in the tropics.

Our present findings show that it is frequent enough in younger children to permit a general review of patients below the age of 5 years. This is the more interesting as the disease is on the wane in most western communities.

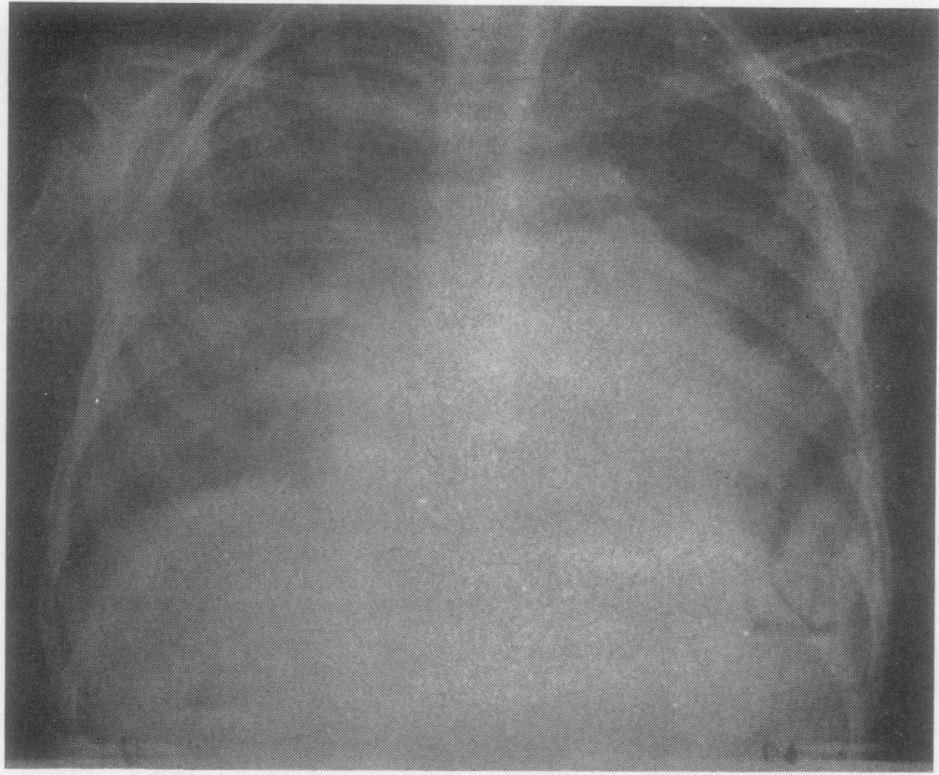

Fig. 1.-Typical appearances of enlarged heart in children under 5 years of age. 


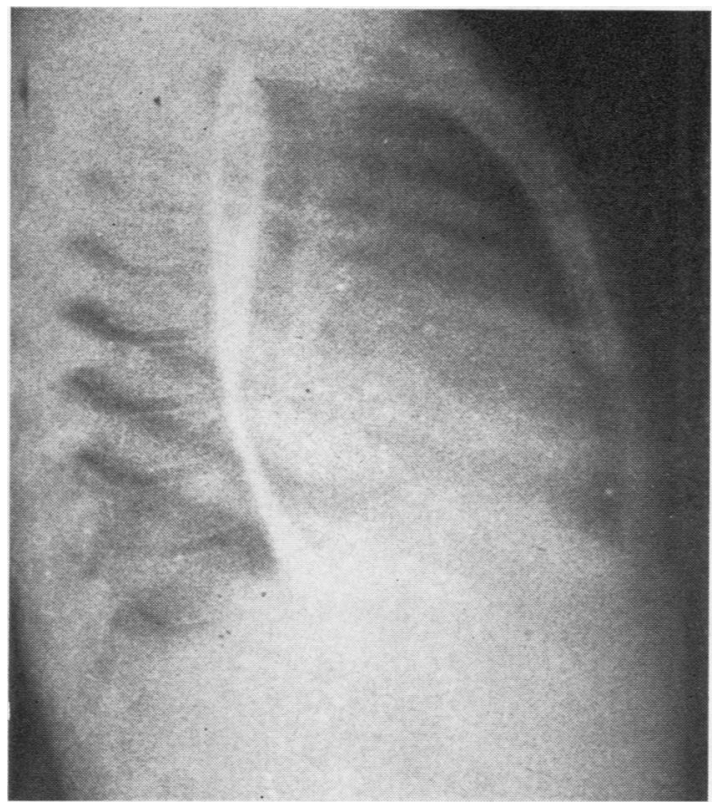

Fig. 2.-Typical appearance of enlarged heart in children under 5 years of age.

The relationship of rheumatic fever to streptococcal sore throat has been repeatedly illustrated and established (Schlesinger, 1930; Sheldon, 1931; Coburn, 1931; Lancefield, 1941; McCarty, 1954; Thomas, 1952). The social conditions of the poorer class (to which patients in the present series belong), with overcrowding, unhealthy habits, and little health education, favour the prevalence of streptococcal sore throat and hence that of rheumatic fever. There is a very high incidence of streptococcal sore throat in the present series. Whether genetic factors are important is difficult to establish; the significantly higher incidence of a familial infection among the younger children may well be partly due to the poor living conditions which affect the whole family.

The relative prevalence of rheumatic mitral incompetence may be due to a more yielding mitral ring or to a more severe form of the disease among younger children.

Cases of severe carditis, with gross cardiac enlargement and with congestive heart failure, occurred with some frequency in these young children, but the difference in incidence from that in the total series was only slight.

\section{Summary}

It is shown that rheumatic fever and rheumatic heart disease are not so rare in the tropics as has previously been supposed. Of 1,000 juvenile patients seen in the course of 4 years, 68 were below age 5 , and 26 of these below age 4 .

Poor living conditions may account for the prevalence of streptococcal sore throat in these young children and in other members of their families.

Rheumatic mitral incompetence was more common in these younger children than in the whole series.

\section{REFERENCES}

Abdin, Z. H. (1960). Iaz. Pediat. Ass., 8, 282.

Coburn, A. F. (1931). "The Factor of Infection in the Rheumatic State." Williams and Wilkins, Baltimore.

Holt, L. E., and McIntosh, R. (1953). "Holt Pediatrics", 12 th ed., p. 826, chap. by G. H. Stollerman.

Ibrahim, M. (1960). Iaz. Pediat. Ass., 8, 236.

Lancefield, R. C. (1941). "Harvey Lectures, 1940-1941", Series 36, p. 251.

McCarty, M. (1954). "Streptococcal Infections." Symposia of the Section of Microbiology, N.Y. Academy of Medicine, No. 7. Columbia University Press, New York.

Schlesinger, B. (1930). Arch. Dis. Childh., 5, 411.

Sheldon, W. (1931). Lancet, 1, 1337.

Thomas, L. (1952). "Rheumatic Fever: A Symposium" (Minnesota Heart Association). University of Minnesota Press, Minneapolis.

La maladie de Bouillaud chez des enfants âgés de moins de 5 ans sous les tropiques

\section{RÉSUMÉ}

On montre que ra maladie de Bouillaud n'est pas aussi rare sous les tropiques qu'on ne l'avait supposé. Sur 1,000 malades juvéniles vus en cours de 4 années, 68 d'entre eux avaient moins de 5 ans et 28 d'entre ceux-ci moins de 4 ans.

Un bas niveau de vie peut expliquer la fréquence de l'angine streptococcique chez ces jeunes enfants et chez d'autres membres de leur familles.

L'insuffisance mitrale rhumatismale était plus commune chez ces jeunes enfants que parmi ceux de la série entière.

La enfermedad de Bouillaud en niños de menos de 5 años de edad en la zona tropical

\section{SUMARIO}

Se demuestra que la enfermedad de Bouillaud es menos rara en la zona tropical que se había supuesto. De 1,000 enfermos juveniles vistos en el curso de 4 años, 68 tuvieron menos de 5 años de edad y 28 de ellos tuvieron menos de 4 años.

Malas condiciones de vida pueden explicar la frecuencia de las infecciones estreptocóccicas de la garganta en niños y en miebros de sus familias.

La insuficiencia mitral reumática fué más común en estos niños que en los de la serie entera. 